\title{
Environmental magnetic record and paleosecular variation data for the last 40 kyrs from the Lake Biwa sediments, Central Japan
}

\author{
Akira Hayashida $^{1}$, Mohammed Ali $^{2 *}$, Yoshiki Kuniko ${ }^{3}$, Hiroyuki Kitagawa ${ }^{4}$, Masayuki Torii ${ }^{5}$, and Keiji Takemura ${ }^{6}$ \\ ${ }^{1}$ Department of Environmental Systems Science, Doshisha University, Japan \\ ${ }^{2}$ Department of Geology and Mineralogy, Kyoto University, Japan \\ ${ }^{3}$ Graduate School of Human and Environmental Studies, Kyoto University, Japan \\ ${ }^{4}$ Graduate School of Environmental Studies, Nagoya University, Japan \\ ${ }^{5}$ Department of Biosphere-Geosphere System Science, Okayama University of Science, Japan \\ ${ }^{6}$ Beppu Geothermal Research Laboratory, Kyoto University, Japan
}

(Received September 29, 2006; Revised May 8, 2007; Accepted May 10, 2007; Online published July 20, 2007)

\begin{abstract}
We have conducted paleomagnetic and environmental magnetic analysis of a sediment piston core recovered from Lake Biwa, central Japan. Tephrochronology and AMS radiocarbon dating showed that this core covers the time period since about $40 \mathrm{kyr}$ BP. The variation of paleomagnetic direction shows a good agreement with the PSV record for the last $10 \mathrm{kyrs}$ from the deeper water site (BIWA SV-3; Ali et al., 1999), although the amplitudes are subdued probably due to the relatively lower accumulation rate at the shallower site. Inclination lows of the pre-Holocene interval are correlated to PSV records reported from the marine sediments off Shikoku and in the Japan Sea. In addition, the variation of magnetic mineral concentration reflects environmental changes during the last glacial period. It is suggested that the flux of fine-grained magnetite, probably associated with greater precipitation, was increased during interstadial periods. The variation of anhysteretic remanent magnetization is likely correlated to the Dansgaard-Oeschger (D-O) cycles recorded in Greenland ice cores. An apparent swing of the PSV curve is recognized at about $27 \mathrm{ka}$, but evidence for the Mono Lake excursion at $32 \mathrm{ka}$ around the D-O events 6 and 7 is unclear. Combination of the detailed paleomagnetic record and the sub-Milankovitch climate cycles thus provides better resolution for understanding geomagnetic secular variation and polarity excursions in space and time.
\end{abstract}

Key words: Environmental magnetism, paleosecular variation, lake sediment, Dansgaard-Oeschger cycles.

\section{Introduction}

Lake sediments are often targeted to obtain records of environmental magnetic record and paleosecular variations (PSVs) of the geomagnetic field (e.g., Evans and Heller, 2003). Most lake basins, however, postdate the last glacial period, providing paleomagnetic records only for the last 10,000 years or a shorter interval in the Holocene. Lake Biwa, located in central Japan (Fig. 1), is a unique freshwater basin which contains continuous sediments at least since the Middle Pleistocene. Several attempts to recover sub-bottom sediments from Lake Biwa have been made, including epoch-making recovery of core samples totaling about $200 \mathrm{~m}$ long in 1971 (Horie, 1984) and drilling of the entire lake sediments through the basement rock in 1982 and 1983 (Takemura, 1990). These studies revealed that the lake basin contains a sedimentary sequence of about $900 \mathrm{~m}$ thick, which was deposited in lacustrine or fluvial environments during the Pliocene and the Pleistocene. The uppermost $250 \mathrm{~m}$ thick unit consists of continuous clay sediments with about 50 volcanic ash layers. Based on

\footnotetext{
*Now at Schlumberger Infomation Solutions, Calgary, Canada.
}

Copyright (c) The Society of Geomagnetism and Earth, Planetary and Space Sciences (SGEPSS); The Seismological Society of Japan; The Volcanological Society of Japan; The Geodetic Society of Japan; The Japanese Society for Planetary Sciences; TERRAPUB. tephrochronological and paleo-climatological data, the 250$\mathrm{m}$ clay unit is correlated to major glacial-interglacial cycles for the last 430,000 years (e.g., Meyers et al., 1993). Hence, Lake Biwa sediment is expected to offer continuous records of past geomagnetic field and environmental changes since the Middle Pleistocene.

Kawai et al. (1972) found the occurrence of anomalous remanent magnetizations in the core samples from Lake Biwa, assigning them to the Blake event, the Biwa I and Biwa II excursions. Yaskawa et al. (1973) also reported records of short excursions, which were then dated at about 18,000 and 49,000 yr BP. After these pioneering works in the 1970's, many records of geomagnetic excursions have been reported from the eastern Asian region, including a Chinese loess/paleosol sequence (Fang et al., 1997) and the sediments of Lake Baikal (Oda et al., 2002). It is difficult, however, to investigate the possible correlation of these reported excursions because questions have been raised about the excursion records from Lake Biwa. These questions result from changes in the chronology of the earlier Lake Biwa studies and from unresolved issues about the reliability of the records of Lake Biwa excursions. The concerns about the older Lake Biwa paleomagnetic studies should be addressed using new cores and more rigorous modern techniques.

We have made a high-resolution studies of multiple pis- 
Table 1. Radiocarbon dates and tephra ages used for the age-model of core BIW95-4 from Lake Biwa.

\begin{tabular}{|c|c|c|c|c|c|c|c|}
\hline $\begin{array}{l}\text { Composite depth } \\
\text { (m) }\end{array}$ & Sample code & Material & Lab number & $\begin{array}{l}{ }^{14} \mathrm{C} \text { age } \\
(\mathrm{yr} \mathrm{BP})\end{array}$ & 1 sigma & $\begin{array}{r}\text { Calendar age } \\
(\mathrm{ka})\end{array}$ & Calibration method* \\
\hline 1.65 & BIW95-4A/102 & leaf & HGr-995 & 2431 & 110 & 2.54 & 1 \\
\hline 1.86 & Kawagodaira & volcanic ash & & & & 2.95 & 2 \\
\hline 2.81 & BIW95-4A/218 & leaf & HGr-1008 & 4910 & 120 & 5.67 & 1 \\
\hline 3.21 & Kikai-Akahoya (K-Ah) & volcanic ash & & 6300 & & 7.25 & $1^{*}$ \\
\hline 4.13 & Ulreung-Oki (U-Oki) & volcanic ash & & & & 10.19 & 2 \\
\hline 6.83 & Sakate & volcanic ash & & & & 18.73 & 2 \\
\hline 7.71 & BIW-95-4-3A/203 & leaf & HGr-1009 & 17770 & 150 & 21.15 & 1 \\
\hline 9.98 & BIW95-4-3B/175 & TOC & HGr-1117 & 22200 & 400 & 25.80 & 2 \\
\hline 10.90 & BIW95-4-4A/15-20 & TOC & HGr-1113 & 25200 & 500 & 28.60 & 2 \\
\hline 11.76 & Aira-Tn (AT) & volcanic ash & & & & 28.78 & 2 \\
\hline 12.00 & BIW95-4-4A/125-130 & TOC & HGr-1114 & 27670 & 600 & 31.50 & 2 \\
\hline 12.75 & BIW95-4-4A/200-205 & TOC & HGr-1115 & 30200 & 800 & 32.30 & 2 \\
\hline 13.46 & BIW95-4-4B/22 & leaf & HGr-1010 & 29900 & 750 & 32.00 & 2 \\
\hline 14.00 & BIW95-4-4B/75 & leaf & HGr-1001 & 32500 & 1400 & 33.90 & 2 \\
\hline 14.66 & BIW95-4-4B/141 & leaf & HGr-1011 & $>37500$ & & & \\
\hline
\end{tabular}

*Calibration of radiocarbon age was made using 1: Stuiver et al. (1998) and 2: Kitagawa and van der Plicht (1998). The ${ }^{14} \mathrm{C}$ age of the K-Ah ash is after Machida and Arai (1978).

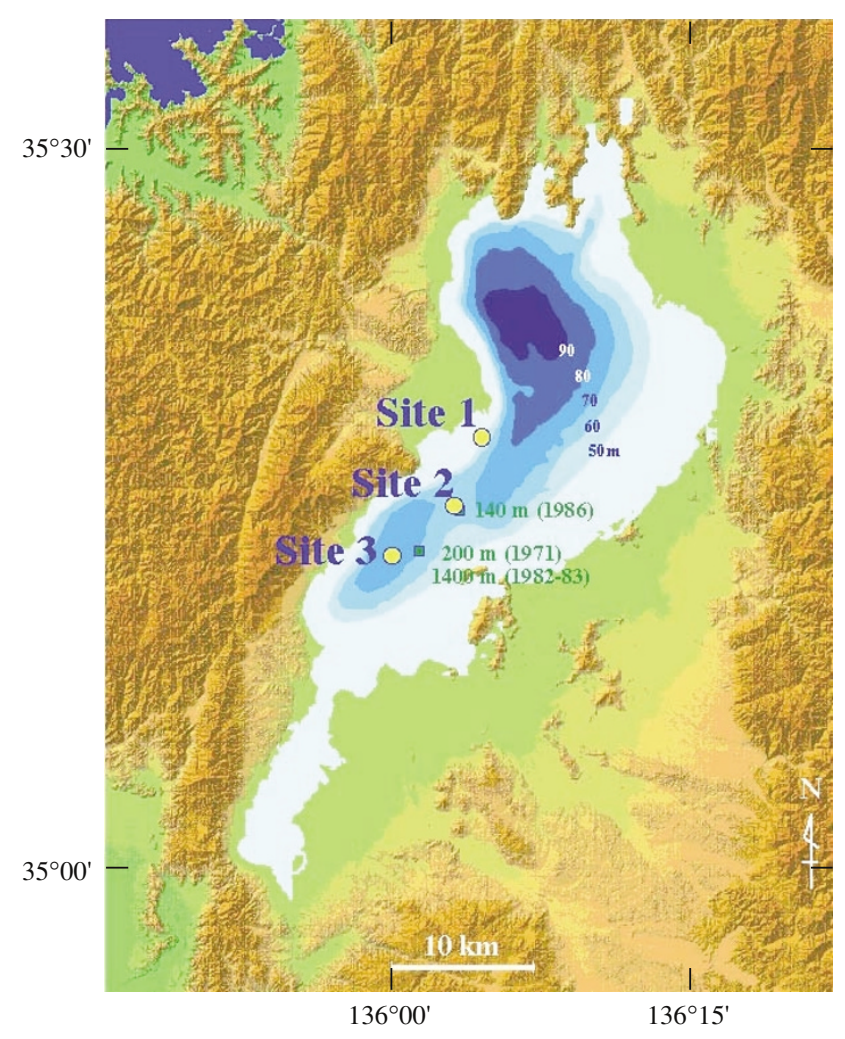

Fig. 1. Map showing location of piston coring sites in Lake Biwa. Locations of previous deep drillings in 1971 and 1982-83 are also shown.

ton cores obtained at three sites in the central part of Lake Biwa (Fig. 1), aiming to produce high-resolution records of PSVs and sub-Milankovitch paleoclimate changes (Takemura et al., 2000). A composite PSV record for the Holocene was constructed by fine-scale adjustment and stacking of three piston cores obtained from Site 3 $\left(35^{\circ} 13^{\prime} \mathrm{N}, 136^{\circ} 00^{\prime} \mathrm{E}\right.$; Ali et al., 1999). Here we describe results of magnetic measurements on a 15 -m long pistoncore from Site $2\left(35^{\circ} 15^{\prime} \mathrm{N}, 136^{\circ} 03^{\prime} \mathrm{E}\right)$, which spans the last 40 kyrs. The rock magnetic parameters provide highresolution records of paleoclimate variability since $40 \mathrm{kyrs}$ ago, including abrupt interstadial events during the last glacial period.

\section{Age Model}

Two piston cores of about 15 to 16 meters long, cores BIW95-4 and BIW95-5, were recovered at Site 2, off Shirahige Beach in a water depth of $67 \mathrm{~m}$ (Fig. 1). These cores were mainly composed of homogeneous bluish gray to gray clay and silty clay, intercalated with 10 volcanic ash layers. Based on lithological description and magnetic susceptibility profiles, we established a detailed core-to-core correlation and obtained the composite depth scale as described by Takemura et al. (2000). Among the 10 volcanic ashes, we found widespread tephra layers such as the Kawagodaira (Kg), Kikai-Akahoya (K-Ah), Ulreung-Oki (U-Oki), Sakate, Daisen-Higashi Daisen (DHg), Daisen-Sasaganaru (DSs; including both plinian and co-ignimbrite units) and Aira-Tn (AT) ashes.

In order to construct the age model for core BIW95-4, we adopted the published ${ }^{14} \mathrm{C}$ age of the $\mathrm{K}$-Ah ash (Machida and Arai, 1978) and the varve counting data of the Kg, UOki, Sakate and AT ashes from Lake Suigetsu (Kitagawa and van der Plicht, 1998), as shown in Table 1. We also collected single pieces of terrestrial macrofossils such as leaves, small branches and insect wings from 9 horizons and additional mud samples from 5 horizons of core BIW954 for radiocarbon dating at the AMS facility of Nagoya University. Among them, 9 AMS ages were obtained and calibrated using INTCAL98 (Stuiver et al., 1998) for the data younger than 22,000 calibrated year B.P., and using the Lake Suigetsu calibration curve (Kitagawa and van der Plicht, 1998) for the older interval (Table 1).

Our radiocarbon dates are generally consistent with the published ages of the widespread tephras, as shown in Fig. 2. However, some ages from bulk total organic carbon (TOC) samples are slightly older when compared with the 


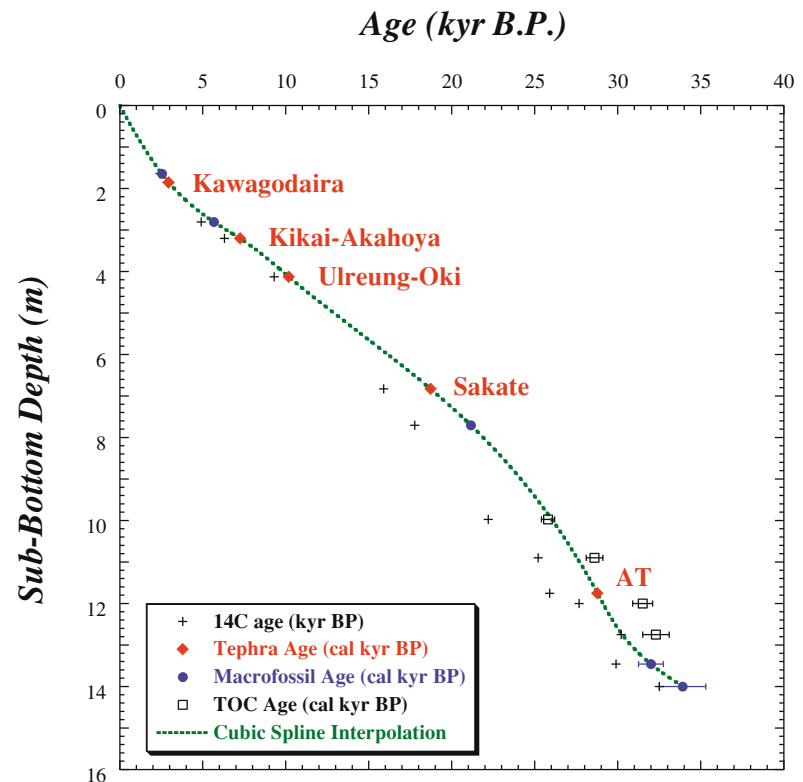

Fig. 2. Age model for Core BIW95-4 from Site 2 based on varve chronology of five widespread tephra layers and five calibrated AMS radiocarbon dates of macrofossils. Slightly older ages from TOC samples were not included for the age model construction.

age of the Aira-Tn (AT) tephra $\left(25.9 \mathrm{kyr}{ }^{14} \mathrm{C}\right.$ BP and 28.8 cal kyr BP; Kitagawa and van der Plicht, 1998). The AT tephra is one of the most important time markers of the last glacial period in Japan, which has yielded radiocarbon ages between 24 and $25 \mathrm{kyr}{ }^{14} \mathrm{C}$ BP (Matsumoto et al., 1987; Murayama et al., 1993; Miyairi et al., 2004). Hence we discarded the four TOC samples and constructed an age model by cubic spline interpolation of the macrofossil data and the tephra ages (Fig. 2). The two cores from Site 2 cover the time interval for about $40 \mathrm{kyrs}$, providing an average sedimentation rate of about $40 \mathrm{~cm} / \mathrm{kyr}$.

\section{Magnetic Measurements}

We made magnetic measurements of 615 cubic samples of $7 \mathrm{~cm}^{3}$, which were sampled at about $2.4 \mathrm{~cm}$ spacing from core BIW95-4. Low-field magnetic susceptibility of these samples, measured on a Bartington Instruments susceptibility meter with a MS1B sensor operating at a frequency of $0.47 \mathrm{kHz}$, were reported in Takemura et al. (2000).

Natural remanent magnetization (NRM) was measured on a cryogenic magnetometer (ScT C-112) at Kyoto University. Sixteen pilot samples were measured after stepwise alternating field (AF) demagnetization up to $60 \mathrm{mT}$ at $5 \mathrm{mT}$ intervals. Additionally, every fifteenth sample was measured after stepwise AF demagnetization at 15, 25, and $35 \mathrm{mT}$. Typical results of the stepwise AF demagnetization are shown in Fig. 3. All pilot samples selected for stepwise AF demagnetization exhibit a stable and well-defined single component. The AF demagnetization at $15 \mathrm{mT}$ was found more than sufficient to remove the soft remanence that may be of viscous origin acquired in the laboratory. Samples that show anomalous direction were examined by additional treatment with 25 and $45 \mathrm{mT}$ AF demagnetization and twelve samples were rejected which had possessed unstable remanence. The remaining samples show less than
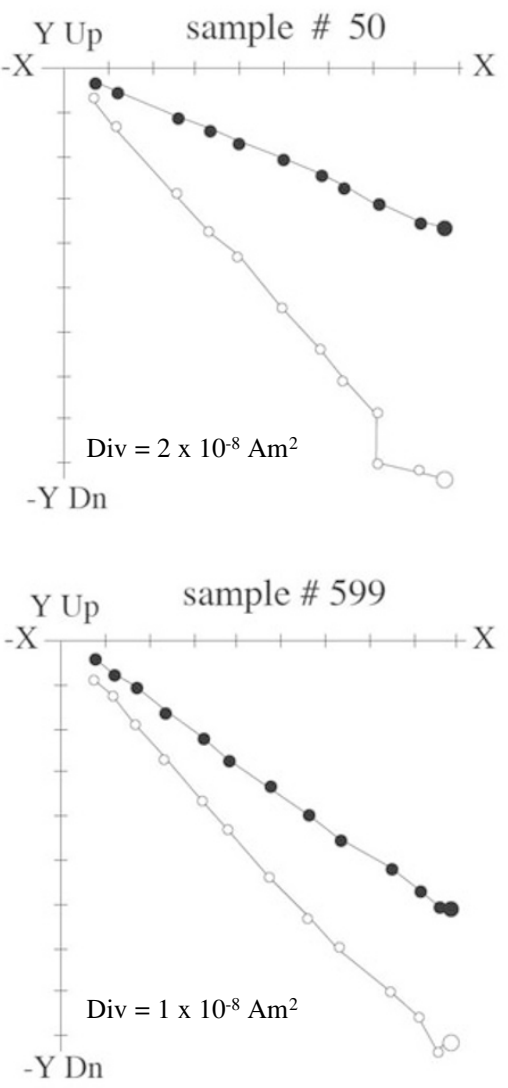

Fig. 3. Representative results of stepwise alternating field demagnetization for samples \#50 from $2.47 \mathrm{~m}$ and \#599 from $15.06 \mathrm{~m}$ core depth. Open and closed symbols indicate projection of vector end-points on the vertical and horizontal planes, respectively.

$2^{\circ}$ of scatter in direction and are believed to be free of secondary overprints. Low-coercivity ferrimagnetic minerals, such as magnetite of pseudo-single domain size, are assumed because the majority of pilot samples lost more than $90 \%$ of their initial remanence between 50 and $60 \mathrm{mT}$. The median destructive field (MDF) for the pilot samples ranged between 23 and $38 \mathrm{mT}$.

After the NRM measurements, we made acquisition experiments of anhysteretic remanent magnetization (ARM) for all the samples and isothermal remanent magnetization (IRM) for half of the samples at about $5 \mathrm{~cm}$ intervals. The ARM was imparted in a $100 \mathrm{mT}$ peak AF with a $0.1 \mathrm{mT}$ steady field, and the ARM susceptibility $\left(\mathrm{k}_{\mathrm{ARM}}\right)$ was obtained by dividing the ARM intensity by the biased field. The IRM was given in a static field at $1 \mathrm{~T}$ produced by an electromagnet. We also obtained back-field IRMs at 0.3 $\mathrm{T}$ in order to calculate the S-ratio $\left(\mathrm{S}_{-0.3 \mathrm{~T}}\right)$ using the definition of Bloemendal et al. (1992): $\mathrm{S}=$ ( ( - back-field IRM / IRM $)+1) / 2$. This ratio, ranging from 0 to 1 , measures the proportion of low-coercivity magnetic minerals to higher coercivity grains.

\section{Variation of Paleomagnetic Directions}

The declination, inclination and intensity profiles plotted on our age model are shown in Fig. 4. The ash layers in the cores were found perpendicular to the core barrel liner suggesting that the corer penetrated vertically during the coring 


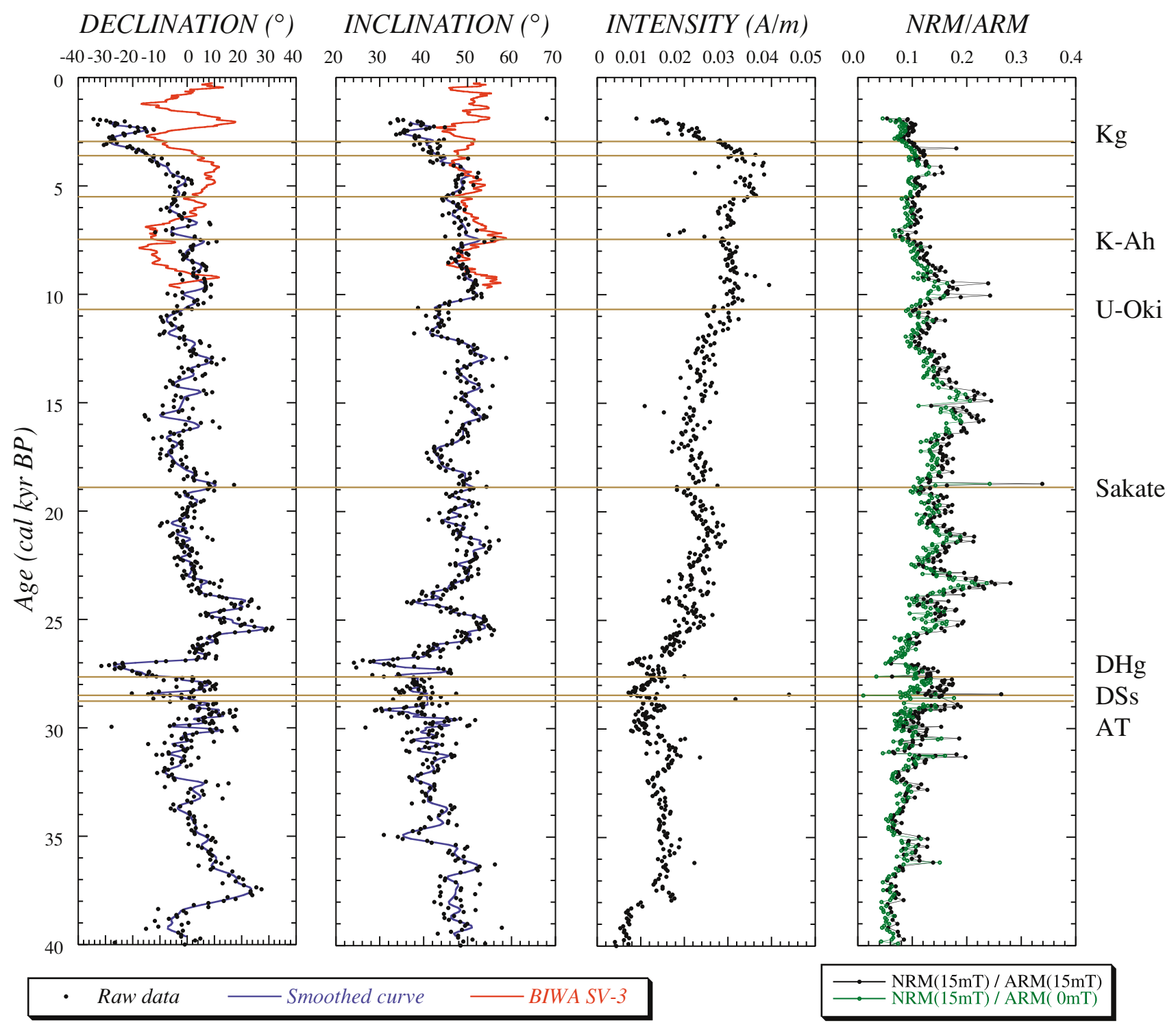

Fig. 4. Variation of declination, inclination and intensity of remanent magnetization observed in the BIW95-4 core after AF demagnetization at 15 mT. The Holocene PSV record obtained at Site 3 in Lake Biwa (BIWA SV-3; Ali et al., 1999) is shown for the last 10 cal kyr. Also shown is variation of the NRM/ARM ratio. The horizontal lines show horizons of volcanic ash layers (See text for the abbreviations). The Daisen-Sasaganaru (DSs) tephra layer consists of the plinian and co-ignimbrite units.

procedure. Therefore inclinations observed relative to the axis of core barrel represent the true inclination relative to the bedding plane. Because the core was not azimuthally oriented, the zero-declination is set for the mean declination of the entire core. We then applied the filter function of seven-point weighted vector mean, the same technique used by Verosub et al. (1986) and Ali et al. (1999). The weighting factors for the filter are $0.037,0.230,0.693$, $1.000,0.693,0.230$ and 0.037 .

A large fluctuation of both declination and inclination was observed in the topmost part younger than $4 \mathrm{cal} \mathrm{kyr}$ $\mathrm{BP}$ and is probably due to mechanical deformation of the sediments during the piston coring. The period between 4 and 23 cal kyr BP shows maximum peak to peak amplitudes of $23^{\circ}$ for declination and $14^{\circ}$ for inclination. The mean inclination calculated for the interval between 4 and 23 cal $\mathrm{kyr} \mathrm{BP}$ is $48.8^{\circ}$, which is close to but slightly shallower than the expected value $\left(54.7^{\circ}\right)$ from the geocentric axial dipole field at the coring site.

The directional variations for the last $10 \mathrm{cal}$ kyr show a good agreement in morphology with the Holocene PSV record from Site 3 of Lake Biwa (BIWA SV-3; Ali et al., 1999), as shown in Fig. 4. However, the amplitudes of the BIW95-4 core record seem to be subdued compared to BIWA SV-3. An average sedimentation rate at Site 3 is about $110 \mathrm{~cm} / \mathrm{ky}$, which is almost 2.5 times higher than that of Site $2(40 \mathrm{~cm} / \mathrm{ky})$. The smaller amplitude observed at Site 2 may be a result of filtering effect or lock-in delay of post depositional remanent magnetization (PDRM). The effect of the PDRM filtering may also attenuate amplitude of the geomagnetic excursion records, as suggested by Thouveny and Creer (1992), Lund and Keigwin (1994), and Roberts and Winklhofer (2004).

As mentioned before, Yaskawa et al. (1973) reported occurrence of negative inclinations at about 18,000 and 49,000 $\mathrm{yr} \mathrm{BP}$ in the core samples of Lake Biwa. Based on recent 

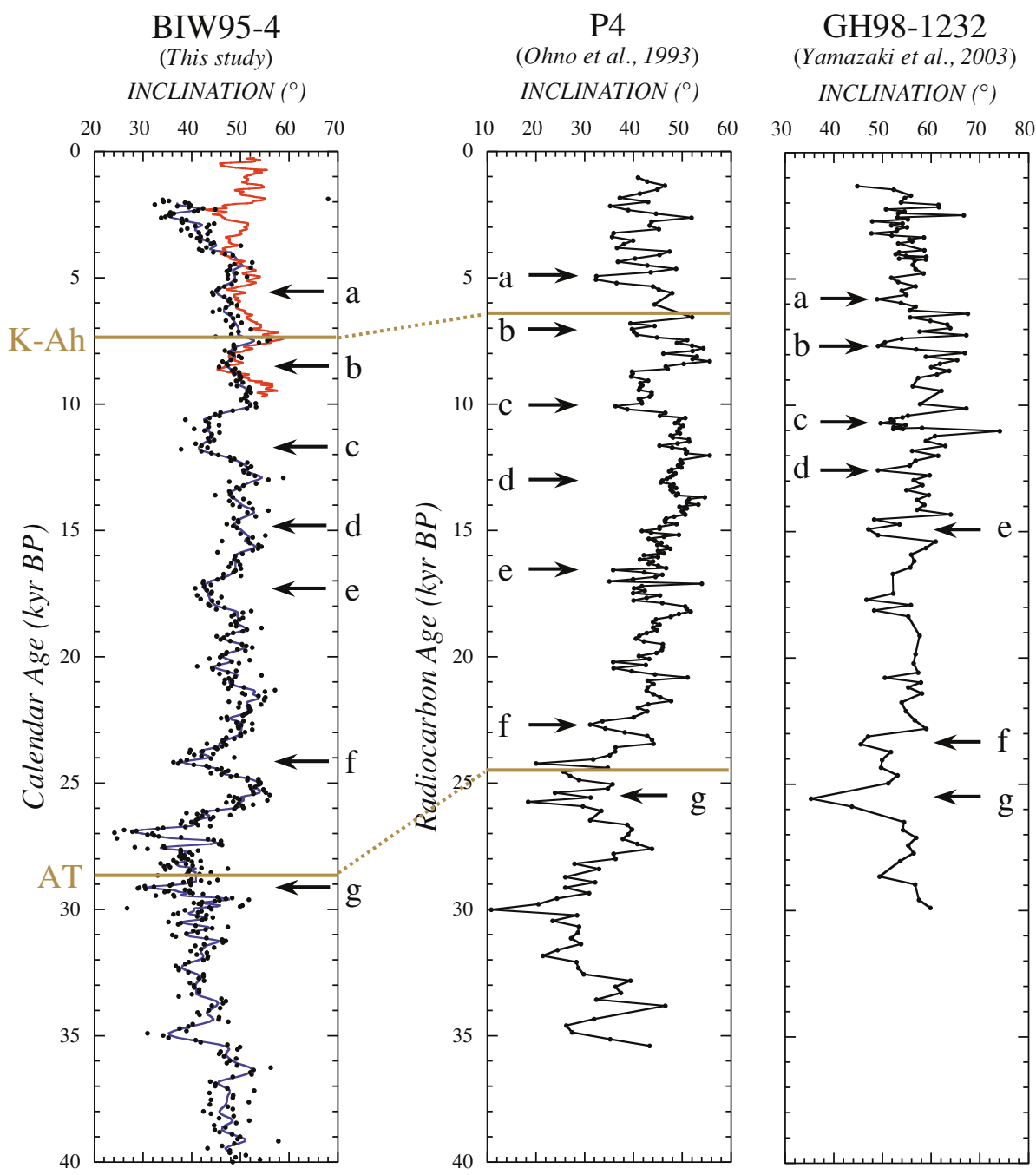

Fig. 5. Comparison of inclination profiles between the core from Lake Biwa (BIW95-4, this study), off Shikoku (Ohno et al., 1993) and the Japan Sea (Yamazaki et al., 2003). The inclination lows, shown by the arrows (a to g), can be correlated between sites, and is partly constrained by the occurrence of the K-Ah and AT tephras.

knowledge of tephrochronology (e.g. Machida et al., 1991), these features correspond to the horizons below the K-Ah ash (7.3 cal kyr BP) and the AT tephra layer itself (28.8 cal kyr BP). While both ashes are found in the BIW95-4 core, we found no correlative anomalous PSV features. On the other hand, the horizon at about 27 cal kyr BP (10.4-10.9 $\mathrm{m})$ in our core is characterized by relatively larger variation in paleomagnetic directions (Fig. 4). Considering the effect of the PDRM filtering, this record implies occurrence of a geomagnetic excursion. It is also noticeable that the NRM/ARM ratio shows a significant drop at this horizon (Fig. 4). Although it is not clear whether this core is suitable for relative paleointensity study, these results suggest a possibility that this interval represents a global geomagnetic feature of a millennial scale.

Our age model for the BIW95-4 core (Fig. 2) locates the excursional feature (27 cal kyr BP) close to estimated ages for the Mono Lake excursion at 24 to $25{ }^{14} \mathrm{C}$ kyr BP (Liddicoat and Coe, 1979) and about $28{ }^{14} \mathrm{C}$ kyr BP (Benson et al., 1998). Recently, there is an intense debate about identification of the Mono Lake excursion at the original site, the Wilson Creek Formation in California. Kent et al. (2002) and Zimmerman et al. (2006) suggested that the anomalous paleomagnetic feature at Mono Lake is correlative with the Laschamp excursion at about $41 \mathrm{cal}$ kyr BP. On the other hand, Benson et al. (2003) showed that the excursion is dated at about 32 cal kyr BP and correlated with a paleointensity low in the NAPIS-75 record (Laj et al., 2000). It is therefore important to delineate the geomagnetic field variation corresponding to the excursion around $32 \mathrm{ka}$ in widely distributed locations. However, the estimated age for the excursional feature in our core is 27 cal kyr BP, which is constrained from the AMS radiocarbon dates and published ages of the widespread tephra layers (Table 1 and Fig. 2). In particular, occurrence of the AT ash indicates that the horizon of our excursional feature is distinctively younger than $30 \mathrm{ka}$. We interpret that the large PSV swing in the BIW954 core represents a geomagnetic field variation associated with a paleointensity low younger than $30 \mathrm{ka}$.

When the inclination variation is compared to paleomagnetic records from marine sediments around the Japanese Islands (Ohno et al., 1993; Yamazaki et al., 2003), there is a good similarity between them. Yamazaki et al. (2003) pointed out that inclination lows found in the cores from 


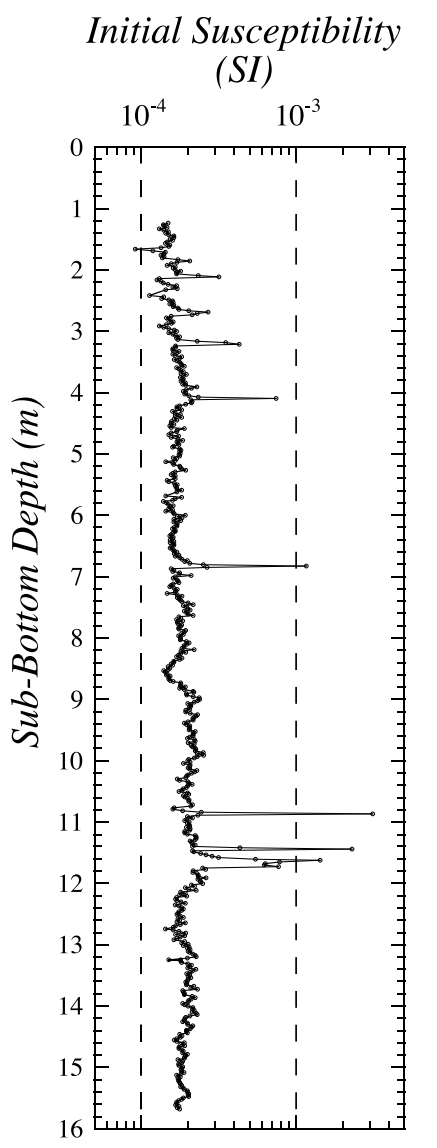

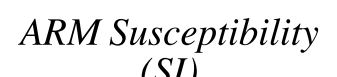
(SI)

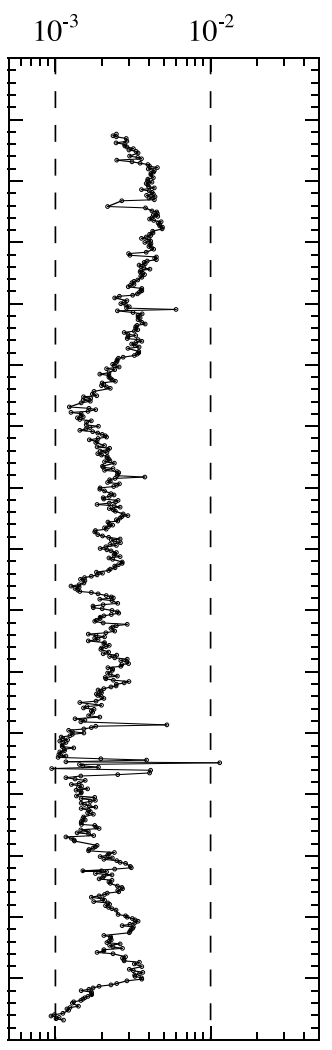

IRM at $1 T$ $(A / m)$

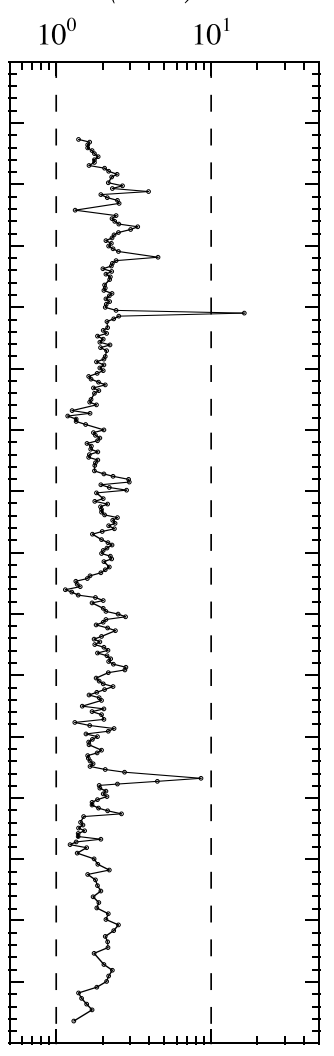

S-ratio $(0.3 T)$

$\begin{array}{llllll}0.90 & 0.92 & 0.94 & 0.96 & 0.98 & 1.00\end{array}$

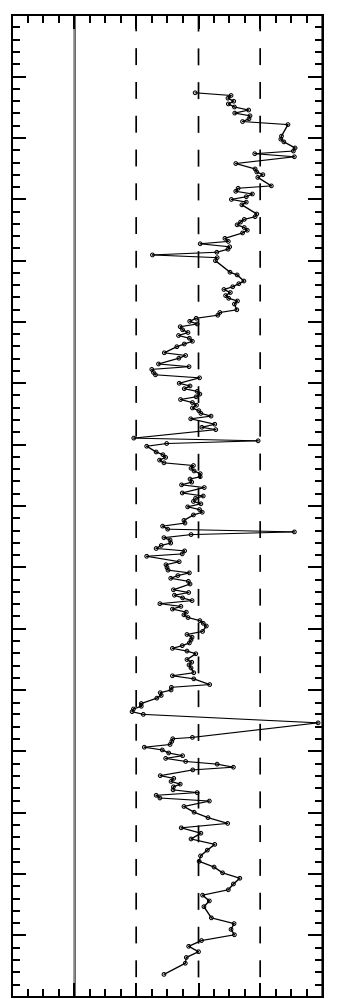

Fig. 6. Depth plots of initial susceptibility, $\mathrm{k}_{\mathrm{ARM}}$, isothermal remanent magnetization of $1 \mathrm{~T}$ and $\mathrm{S}$-ratio at $0.3 \mathrm{~T}$.

the Japan Sea $\left(44^{\circ} 48^{\prime} \mathrm{N}, 139^{\circ} 42^{\prime} \mathrm{E}\right.$; Yamazaki et al., 2003) and off Shikoku $\left(32^{\circ} 09^{\prime} \mathrm{N}, 133^{\circ} 54^{\prime} \mathrm{E}\right.$; Ohno et al., 1993) are well correlated each other, as shown in Fig. 5. Age models for both marine records are based on AMS radiocarbon dates of planktonic foraminifers, which were not converted to calendar ages. Nevertheless we can extend the inclination correlation to the Lake Biwa sediments, partly supported by common occurrence of the K-Ah and AT tephra deposits (Fig. 5). The regional similarity in inclination strongly suggests that these inclination features reflect variation of the geomagnetic field around Japan for the last 40 kyrs.

\section{Environmental Magnetic Record}

Figure 6 shows depth profiles of the low-field magnetic susceptibility, $\mathrm{k}_{\mathrm{ARM}}$, IRM of $1 \mathrm{~T}$ and S-ratio at $0.3 \mathrm{~T}$. The variations of these parameters show outstanding peaks at several horizons, which correspond to volcanic ash layers. Except for these peaks, the three parameters covary with each other at some intervals, but the correlation is not so significant, in particular between the initial susceptibility and the $\mathrm{k}_{\mathrm{ARM}}$. Because the initial susceptibility is measured in a magnetic field, it may be controlled by diamagnetic and paramagnetic minerals rather than the remanence carriers. It is generally believed that the ARM is more sensitive to the presence of small magnetite grains compared to low-field susceptibility or saturation IRM (e.g., King et al., 1983; Bloemendal et al., 1993). The ARM results suggest that the abundance of fine-grained magnetite is increased at the interval above $5 \mathrm{~m}$, which corresponds to the post- glacial period. The IRM and S-ratio data shows consistent variation with the ARM. The interval between 11 and $12 \mathrm{~m}$ deep seems to be characterized by relatively coarse-grained magnetite, which is probably explained by the presence of several volcanic ash layers at this interval.

Figure 7 shows the variation of total organic carbon (TOC) content (Yamada, 2004) and $\mathrm{k}_{\mathrm{ARM}}$ from the BIW954 core. The TOC data shows increased value in the upper intervals, which correspond to the post-glacial period. The increased TOC values suggest that the post-glacial period is characterized by enhanced aquatic productivity and an increased flux of wash-in nutrients and organic matter, as described by Meyers et al. (1993). As shown in Fig. 7, the amount of magnetic minerals represented by the $\mathrm{k}_{\mathrm{ARM}}$ shows a variation similar to the total organic carbon content. The $\mathrm{k}_{\mathrm{ARM}}$ data suggest that the fine-grained magnetite flux was also increased during warm periods, probably associated with enhanced precipitation.

We also compared the magnetic concentration in the Lake Biwa sediments with the oxygen isotope records from the Greenland ice core, NGRIP (Johnsen et al., 2001; North Greenland Ice Core project members, 2004) in Fig. 7. The $\mathrm{k}_{\mathrm{ARM}}$ data is characterized by abrupt increases of fine-grained magnetite at several intervals during the last glacial period. These peaks may represent interstadial events, which were presumably linked with the DansgaardOeschger (D-O) cycles (Dansgaard et al., 1993). In particular, the $\mathrm{k}_{\mathrm{ARM}}$ data between 30 and 40 cal kyr BP show similar variations with the ice core record of the D-O events 5 


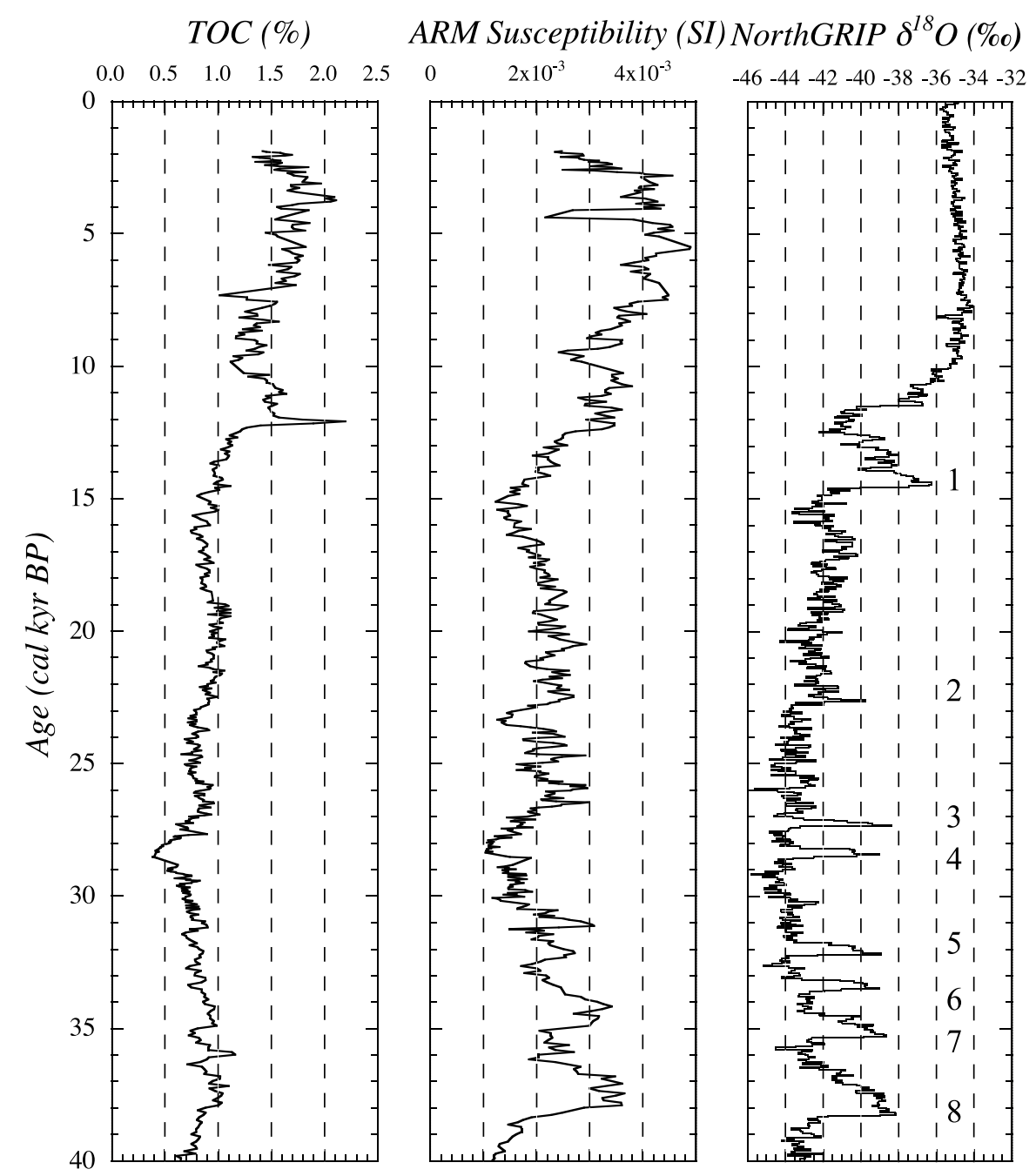

Fig. 7. Comparison of the total organic carbon (TOC) content (Yamada, 2004) and the magnetic concentration ( $\mathrm{k}_{\mathrm{ARM}}$ ) of core BIW95-4 from Lake Biwa. The variation of $\mathrm{k}_{\mathrm{ARM}}$ also shows good similarity with the oxygen isotope record from the Greenland ice core (NGRIP; North Greenland Ice Core Project members, 2004). The numbers (1 to 8) show the interstadial events in the Dansgaard-Oeschger cycles.

to 8 , although the younger D-O events are not clearly identified. Evidence of the Younger Dryas cold event is not observed in the rock magnetic signature between 10 and $15 \mathrm{ka}$, where the $\mathrm{k}_{\mathrm{ARM}}$ record shows a gradual increase contrasting to the Greenland ice core isotope record.

As mentioned before, the Mono Lake excursion was suggested to correspond to a paleointensity low at about $32 \mathrm{ka}$ (Benson et al., 2003). It was also reported that a peak of ${ }^{36} \mathrm{Cl}$ concentration occurs between the D-O events 6 and 7 at about $32 \mathrm{ka}$ in the GRIP ice core (Wagner et al., 2000). Our assignment of the $\mathrm{k}_{\mathrm{ARM}}$ record with the $\mathrm{D}-\mathrm{O}$ events 5 to 8 suggests that at least a directional feature of the Mono Lake excursion was not recorded at the corresponding interval in the Lake Biwa sediments. Significant directional features were also not observed in core samples from Lake Baikal (Peck et al., 1996) and the western Equatorial Pacific (Blanchet et al., 2006; Leduc et al., 2006), although these cores show paleointensity lows which can be linked to the Mono Lake excursion. The Laschamp excursion is dated at $40.4 \pm 2.0 \mathrm{ka}$ (Guillou et al., 2004) and assigned near the D-O event 10 (Kissel et al., 1999). Unfortunately our core did not reach to the interval of the D-O event 10 , where a record of the Laschamp excursion may be observed.

\section{Conclusion}

Detailed paleomagnetic analysis of Core BIW95-4 from Lake Biwa provided a record of geomagnetic field for the last 40 cal kyr, which is comparable to the Holocene PSV records obtained from the deeper site of Lake Biwa and also with the older inclination features reported from the Japan Sea and off Shikoku. In addition, this research suggests that rock magnetic properties of the sediment core form Lake Biwa provide an interpretable proxy of environmental change such as the Dansgaard-Oeschger cycles. We can expect to observe similar paleoclimatically sensitive mineral magnetic records from the older sediments in Lake Biwa. Combination of the detailed paleomagnetic record and the sub-Milankovitch climate cycles provides a clue to understand geomagnetic secular variation and polarity excursions in space and time. We therefore propose a future drilling project in Lake Biwa to obtain high-resolution paleomagnetic and mineral magnetic records of fine-grained sedimentary sequences in order to extend the records presented here further back in time.

Acknowledgments. We acknowledge Makoto Okamura and Hiromi Matsuoka for their support with the coring work in Lake 
Biwa. We thank K. Yamada for providing the TOC data. This manuscript was greatly improved by the reviews of $\mathrm{N}$. Thouveny and J. A. Peck. This work was partly supported by the Grant-inAid for Scientific Research from Japan Society for the Promotion of Science (19204050).

\section{References}

Ali, M., H. Oda, A. Hayashida, K. Takemura, and M. Torii, Holocene paleomagnetic secular variation at Lake Biwa, central Japan, Geophys. J. Int., 136, 218-228, 1999.

Benson, L. V., S. P. Lund, J. W. Burdett, M. Kashgarian, T. P. Rose, J. Smoot, and M. D. Schwartz, Correlation of Late-Pleistocene lake level oscillations in Mono Lake, California, with North Atlantic climate events, Quaternary Research, 49, 1-10, 1998.

Benson, L., J. C. Liddicoat, J. Smoot, A. Sarna-Wojcicki, R. Negrini, and S. Lund, Age of the Mono Lake excursion and associated tephra, Quaternary Science Reviews, 22, 135-140, 2003.

Blanchet, C. L., N. Thouveny, and T. de Garidel-Thoron, Evidence for multiple paleomagnetic intensity lows between 30 and $50 \mathrm{ka}$ BP from a western Equatorial Pacific sedimentary sequence, Quaternary Science Reviews, 25, 1039-1052, 2006.

Bloemendal, J., J. W. King, F. R. Hall, and S.-J. Doh, Rock magnetism of Late Neogene and Pleistocene deep-sea sediments: relationship to sediment source, diagenetic processes, and sediment lithology, J. Geophys. Res., 97, 4361-4375, 1992.

Bloemendal, J., J. W. King, A. Hunt, P. B. deMenocal, and A. Hayashida, Origin of the sedimentary magnetic record at Ocean Drilling Program sites on the Owen Ridge, western Arabian Sea, J. Geophys. Res., 98, 4199-4219, 1993.

Dansgaard, W. et al., Evidence for general instability of past climate from a 250-kyr ice core record, Nature, 364, 218-220, 1993.

Evans, M. E. and F. Heller, Environmental Magnetism-Principles and Applications of Enviromagnetics, 293 pp., Academic Press, 2003.

Fang, X.-M., J.-J. Li, R. Van der Voo, C. M. Niocaill, X.-R. Dai, R. A. Kemp, E. Derbyshire, J.-X. Cao, J.-M. Wang, and G. Wang, A record of the Blake Event during the last interglacial paleosol in the western Loess Plateau of China, Earth Planet. Sci. Lett., 146, 73-82, 1997.

Guillou, H., B. S. Singer, C. Laj, C. Kissel, S. Scaillet, and B. R. Jicha, On the age of the Laschamp geomagnetic excursion, Earth Planet. Sci. Lett., 227, 331-343, 2004.

Horie, S. (ed.), Lake Biwa, 654 pp. Dr. W. Junk Publishers, Dordrecht, 1984.

Johnsen, J. S., D. Dahl-Jensen, N. Gundestrup, J. P. Steffensen, H. B. Clausen, H. Miller, V. Masson-Delmotte, A. E. Sveinbjörnsdottir, and J. White, Oxygen isotope and palaeotemperature records from six Greenland ice-core stations: Camp Century, Dye-3, GRIP, GISP2, Renland and NorthGRIP, Journal of Quaternary Science, 16, 299-307, 2001.

Kawai, N., K. Yaskawa, T. Nakajima, M. Torii, and S. Horie, Oscillating geomagnetic field with a recurring reversal discovered from Lake Biwa, Proc. Japan Acad., 48, 186-190, 1972.

Kent, D. V., S. R. Hemming, and B. D. Turrin, Laschamp excursion at Mono Lake?, Earth Planet. Sci. Lett., 197, 151-164, 2002.

King, J. W., S. K. Banerjee, and J. Marvin, A new rock-magnetic approach to selecting sediments for geomagnetic paleointensity studies: application to paleointensity for the last 4000 years, J. Geophys. Res., 88, 59115921, 1983.

Kissel, C., C. Laj, L. Labeyrie, T. Dokken, A. Voelker, and D. Blamart, Rapid climatic variations during climatic stage 3: Magnetic analysis of North Atlantic sediments, Earth Planet. Sci. Lett., 171, 489-502, 1999.

Kitagawa, H. and J. van der Plicht, A 40,000-year varve chronology from Lake Suigetsu, Japan: Extension of the radiocarbon calibration curve, Radiocarbon, 40, 505-516, 1998.

Laj, C., C. Kissel, A. Mazaud, J. E. T. Channell, and J. Beer, North Atlantic paleointensity stack since $75 \mathrm{ka}$ (NAPSIS-75) and the duration of the Laschamp event, Phil. Trans. R. Soc. London, A, 358, 1009-1025, 2000.

Leduc, G., N. Thouveny, D. L. Bourlès, C. L. Blanchet, and J. T. Carcaillet, Authigenic ${ }^{10} \mathrm{Be} /{ }^{9} \mathrm{Be}$ signature of the Laschamp excursion: A tool for global synchronisation of paleoclimatic archives, Earth Planet. Sci. Lett., 245, 19-28, 2006.

Liddicoat, J. C. and R. S. Coe, Mono Lake geomagnetic excursion, $J$. Geophys. Res., 84, 261-271, 1979.

Lund, S. and L. Keigwin, Measurement of the degree of smoothing in sediment paleomagnetic secular variation records: an example from late Quaternary deep-sea sediments of the Bermuda Rise, western North Atlantic Ocean, Earth Planet. Sci. Lett., 122, 317-330, 1994.
Machida, H. and F. Arai, Akahoya Ash-a Holocene widespread tephra erupted from the Kikai Caldera, south Kyushu, Japan, The Quaternary Research (Japan), 17, 143-163, 1978.

Machida, H., F. Arai, and T. Yokoyama, Re-examination of maker-tephra layers in the $200 \mathrm{~m}$ Biwa-lake core, The Quaternary Research (Japan), 30, 439-442, 1991.

Matsumoto, E., Y. Maeda, K. Takemura, and S. Nishida, New radiocarbon age of Aira-Tn ash (AT), The Quaternary Research (Japan), 26, 79-83, 1987.

Meyers, P. A., K. Takemura, and S. Horie, Reinterpretation of Late Quaternary sediment chronology of Lake Biwa, Japan, from correlation with marine glacial-interglacial cycles, Quaternary Res., 39, 154-162, 1993.

Miyairi, Y., K. Yoshida, Y. Miyazaki, H. Matsuzaki, and I. Kaneoka, Improved ${ }^{14} \mathrm{C}$ dating of a tephra layer (AT tephra, Japan) using AMS on selected organic fractions, Nuclear Instruments and Methods in Physics Research B., 223-224, 555-559, 2004.

Murayama, M., E. Matsumoto, T. Nakamura, M. Okamura, H. Yasuda, and A. Taira, Re-examination of the eruption age of Aira-Tn Ash (AT) obtained from a piston core off Shikoku-determined by AMS ${ }^{14} \mathrm{C}$ dating of planktonic foraminifera-, J. Geol. Soc. Japan, 99, 787-798, 1993

North Greenland Ice Core Project members, High-resolution record of Northern Hemisphere climate extending into the last interglacial period, Nature, 431, 147-151, 2004.

Oda, H., K. Nakamura, K. Ikehara, T. Nakano, M. Nishimura, and O. Khlystov, Paleomagnetic record from Academician Ridge, Lake Baikal: a reversal excursion at the base of marine oxygen isotope stage 6., Earth Planet. Sci. Lett., 202, 117-132, 2002.

Ohno, M., Y. Hamano, M. Murayama, E. Matsumoto, H. Iwakura, T. Nakamura, and A. Taira, Paleomagnetic record over the past 35000 years of a sediment core from off Shikoku, Southwest Japan, Geophys. Res. Lett., 20, 1395-1398, 1993.

Peck, J. A., J. W. King, S. W. Colman, and V. A. Kravchinsky, An 84 kyr paleomagnetic record from the sediments of Lake Baikal, Siberia, $J$. Geophys. Res., 101, 11365-11385, 1996.

Roberts, A. P. and M. Winklhofer, Why are geomagnetic excursions not always recorded in sediments? Constraints from post-depositional remanent magnetization lock-in modeling, Earth Planet. Sci. Lett., 227, 345-359, 2004.

Stuiver, M., P. J. Reimer, E. Bard, J. W. Beck, G. S. Burr, K. A. Hughen, B. Kromer, G. McCormac, J. Van Der Plicht, and M. Spurk, INTCAL98 radiocarbon age calibration, 24,000-0 cal BP, Radiocarbon, 40, 1041 1083, 1998.

Takemura, K., Tectonic and climatic record of the Lake Biwa, Japan, region provided by the sediments deposited since Pliocene times, Palaeogeogr. Palaeoclimat. Palaeoecol., 78, 185-193, 1990.

Takemura, K., A. Hayashida, M. Okamura, H. Matsuoka, M. Ali, Y. Kuniko, and M. Torii, Stratigraphy of multiple piston-core sediments for the last 30,000 years from Lake Biwa, Japan, J. Paleolimnol., 23, 185199, 2000.

Thouveny, N. and K. M. Creer, Geomagnetic excursions in the last 60 thousand years: ephemeral secular variation features, Geology, 20, 399402, 1992.

Verosub, K. L., P. J. J. Mehringer, and P. Waterstraat, Holocene secular variation in western North America: Paleomagnetic record from Fish Lake, Harney County, Oregon, J. Geophys. Res., 91, 3609-3623, 1986. Wagner, G., J. Beer, C. Laj, C. Kissel, J. Masarik, R. Muscheler, and H.-A. Synal, Chlorine-36 evidence for the Mono Lake event in the Summit GRIP ice core, Earth Planet. Sci. Lett., 181, 1-6, 2000.

Yamada, K., Last 40 ka climate changes as deduced from the lacustrine sediments of Lake Biwa, central Japan, Quaternary Int., 123-125, 43 $50,2004$.

Yamazaki, T., A. L. Abdeldayem, and K. Ikehara, Rock-magnetic changes with reduction diagenesis in Japan Sea sediments and preservation of geomagnetic secular variation in inclination during the last 30,000 years, Earth Planets Space, 55, 327-340, 2003.

Yaskawa, K., T. Nakajima, N. Kawai, M. Torii, N. Natsuhara, and S. Horie, Palaeomagnetism of a core from Lake Biwa (I), J. Geomag. Geoelectr., 25, 447-474, 1973.

Zimmerman, S. H., S. R. Hemming, D. V. Kent, and S. Y. Searle, Revised chronology for late Pleistocene Mono Lake sediments based on paleointensity correlation to the global reference curve, Earth Planet. Sci. Lett., 252, 94-106, 2006.

A. Hayashida (e-mail: ahay@mail.doshisha.ac.jp), M. Ali, Y. Kuniko, H. Kitagawa, M. Torii, and K. Takemura 